\title{
Isotopic fingerprinting of fluid circulation at the terminal stage of the Himalayan orogeny: An example from the Himalayan forearc basin, Indus Tsangpo suture zone, Ladakh, India
}

\author{
Aditya Kharya ${ }^{1}$, Himanshu K Sachan ${ }^{1, *}$, M Santosh ${ }^{2,3}$, \\ Sunil K Singh ${ }^{4}$ and SameER K Tiwari ${ }^{1}$ \\ ${ }^{1}$ Wadia Institute of Himalayan Geology, Dehradun, India. \\ ${ }^{2}$ School of Earth Science and Resources, University of Geosciences, Beijing 100 083, People's Republic of China. \\ ${ }^{3}$ Department of Earth Sciences, University of Adelaide, Adelaide, SA 5005, Australia. \\ ${ }^{4}$ CSIR-National Institute of Oceanography, Goa, India. \\ *Corresponding author. e-mail: hksachan@wihg.res.in
}

MS received 22 May 2018; revised 22 November 2018; accepted 26 November 2018; published online 14 May 2019

Quartz and calcite veins are omnipresent in the Indus basin sedimentary rocks (IBSRs) of the Indus Tsangpo suture zone (ITSZ) which were formed by the accumulation of sediments derived from both sides of the tectonic plate. These veins appear to have formed just after the sediment diagenesis and were deformed together with the IBSR. The veins were studied for their rare earth elemental and isotopic geochemistry $(\mathrm{C}-\mathrm{O}-\mathrm{Sr}-\mathrm{Pb})$. The light rare earth element/mid rare earth element with an $\mathrm{Eu} / \mathrm{Eu}^{*}$ ratio of the veins (quartz and calcite) is $>1$ for the northern side (Tibetan side) and $<1$ for the southern side, indicating a mantle/magmatic and marine-related fluid source, respectively. The carbon, oxygen and strontium isotopes range from $-14 \%$ to $-1 \%$ VPDB, $+5.7 \%$ to $+24.9 \%$ Vienna standard mean ocean water and 0.7056 to 0.7099 , respectively. The $\mathrm{Sr}-\mathrm{O}$ mixing model points towards the mantleenriched fluid on the northern side of the IBSR, whereas on the southern side, the fluid was nearly marine. The intermixing of the fluid took place in the middle part of the Indus basin sediments comprising a mixed litho-unit succession. Similar characteristics of vein fluids with the host rocks indicate the derivation of fluids from the associated host IBSR, further substantiated by the lead isotopic systematics.

Keywords. Fluids; Indus Tsangpo suture zone; Ladakh; C-O-Sr-Pb isotopes; NW Himalayas.

\section{Introduction}

The Indus basin sedimentary rocks (IBSRs) were developed in the Ladakh magmatic forearc setup, within the Indus Tsangpo suture zone (ITSZ) due to the India-Asia collision during the Middle Eocene era (Searle 1986; Garzanti et al. 1987;
Henderson et al. 2010a, b). The IBSR consists of sediments derived from both sides of the tectonic plate. The subduction zone plays a crucial role in the global geochemical cycle, transferring chemical components into the mantle which are returned to the crust (and atmosphere) through arc volcanism. Most of the fluids get trapped either 
within the hydrous minerals or as pore water in the oceanic crust and superjacent sediments. The role of fluids during metamorphism and exhumation of the suture zone remains ambiguous in the ITSZ. Fluid flow in the subduction zone is driven mainly by the expulsion of sediment pore (formation) waters during the burial, diagenetic and prograde metamorphism of sedimentary rocks and the dehydration of the subducting slab.

The vein-forming fluids were introduced into the sedimentary units of the IBSR immediately after the deposition and the subsequent burial phase. The quartz-calcite veins are omnipresent in the mud/silt stone units of the IBSR. To understand the source and mechanism of vein formation of the ITSZ, two transverse sections of the IBSR, namely, Nimmu-Chilling (NC) and Lato-MiruUpshi (LMU), were selected. The sections are alike in terms of lithologies and sedimentation processes and are bounded by the Indus thrust in the north and the Zanskar thrust in the south. The Indus basin sediments were deposited until the Early Miocene era (Brookfield and Andrews-Speed 1984;
Van Haver 1984; Garzanti and Van Haver 1988; Searle et al. 1990; Clift et al. 2000; Sinclair and Jaffey 2001; Clift et al. 2002a; Henderson et al. 2011); after that, the veins were developed. This study is focused on the sources of the vein fluids and their emplacement mechanism during the terminal phase of the Himalayan orogeny, across the ITSZ.

\section{Geological setting}

The Cenozoic IBSRs including the Indus Molasse, Indus formation or Kargil formation (Shah et al. 1976; Frank 1977; Gansser 1977; Thakur 1981; Searle et al. 1990; Clift et al. 2001; Wu et al. 2007) were deposited as a succession of clastic and carbonate sedimentary rocks within the ITSZ. The IBSRs are well exposed along the ITSZ in the forearc setup of the Ladakh magmatic arc (LMA), consisting of sediments derived from both sides of the Indian plate (i.e., Zanskar platform or the Tethyan Himalayas) and the active Asian margin (AAM) (figure 1A). The northern margin of

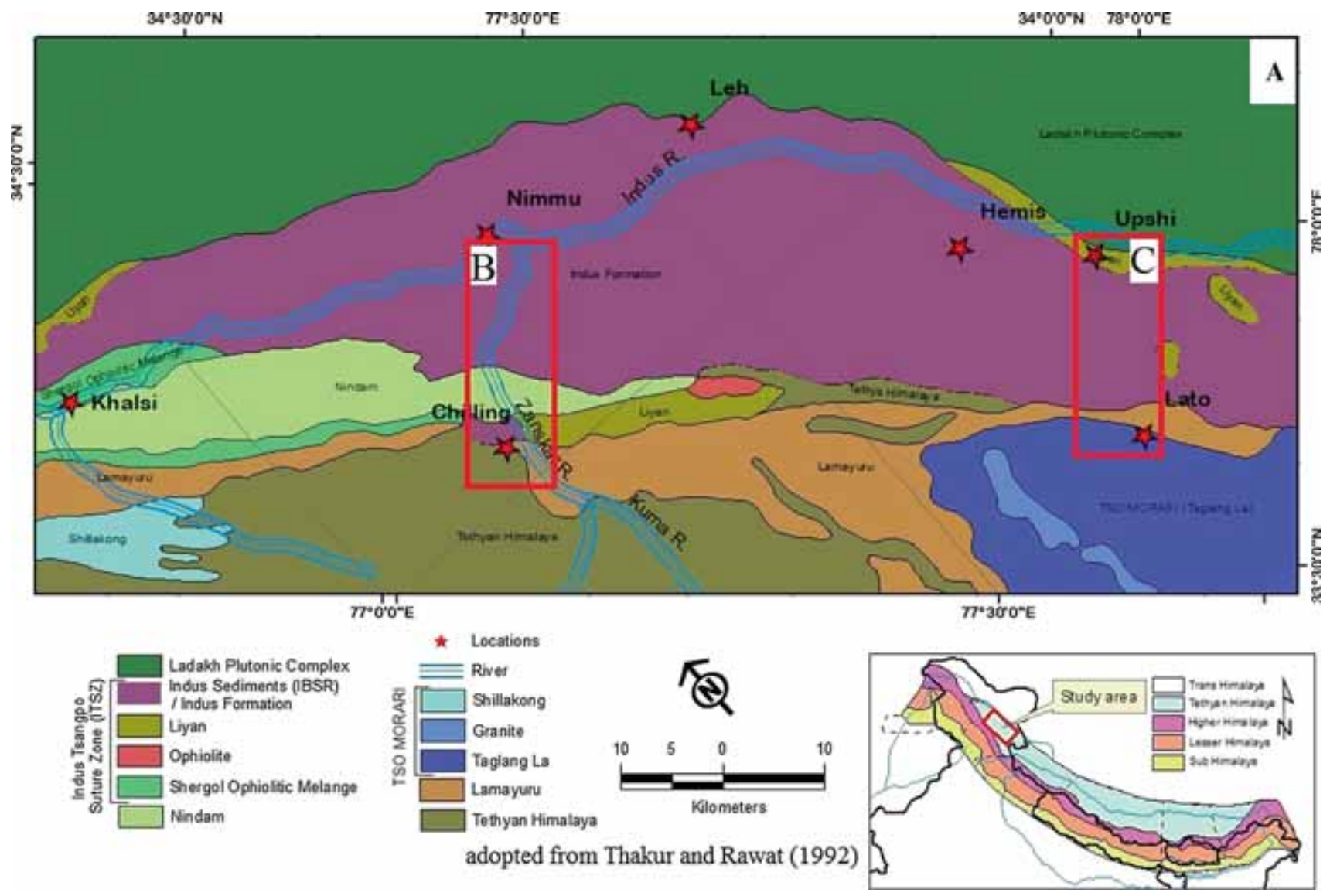

Figure 1. Geological map of the study area: (A) geological map of the NW Himalayas adopted from Thakur and Rawat (1992); (B) geological map of the NC section (Henderson et al. 2010b) and (C) location of the LMU section (Henderson et al. 2011). 

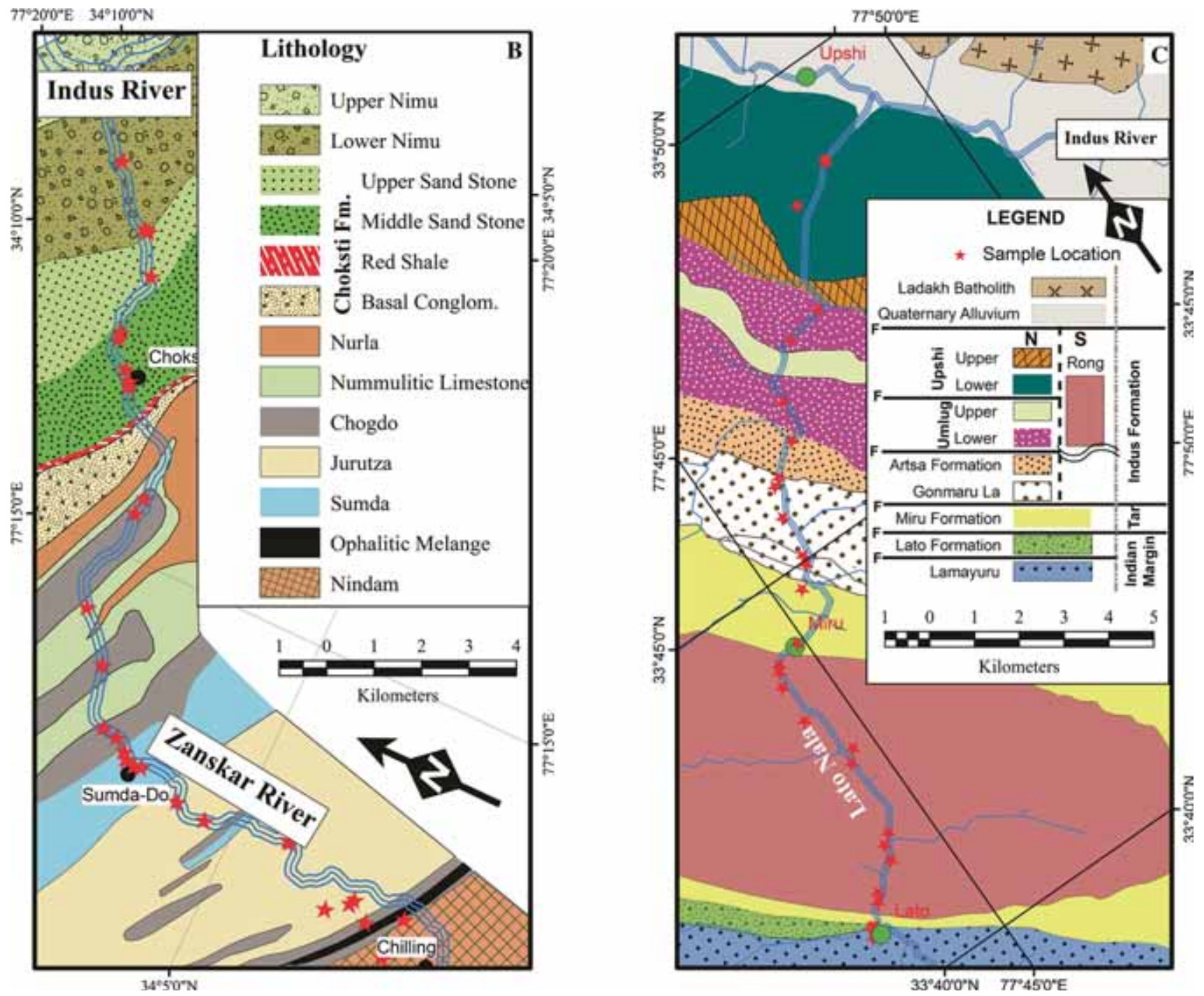

Figure 1. (Continued.)

the IBSR is demarcated by the LMA, whereas the southern margin, by the Zanskar platform or the Tethyan Himalayas (figure 1A). The eastern and western margins of the ITSZ are bounded by ophiolite and ophiolitic mélange of Zildat and Shergol, respectively (figure 1A). The IBSR mainly comprises clasts, which are folded and thrusted, are unconformably overlain by the Lamayuru formation and underlain by the Ladakh batholith in the southern and northern margins, respectively (Tonarini et al. 1993; Clift et al. 2001) (figure 1A). The Ladakh batholith, developed to the north of the IBSR prior to the India-Asia continental collision between 49 and $61 \mathrm{Ma}$ (Weinberg 1997), is also known as the AAM. The southern margin of the IBSR overlies the upper Cretaceous-Palaeogene forearc basin of the Asian margin.

The IBSRs comprise the Tar Group and the Indus Group of sediments. The Tar Group of sediments comprise the Jurutze, Sumda and Chogdo formations. The oldest lithological unit is known as the Jurutze formation, which was developed prior to the continental collision (Garzanti and Van Haver 1988; Clift et al. 2001). The Jurutze formation of the Late Albian (Garzanti and Van Haver 1988) to the earliest Eocene age comprises grey shales and siltstones, grey phyllites and fine- to medium-grained black-grey-green sandstones with black limestones. The Jurutze formation is overlain by the Sumda formation (figure 1B) which consists of brown-silver-grey, thinly laminated phyllites and fine- to coarse-grained sandstones. The Jurutze and Sumdo formations are marine, having foraminifera of the Maastrichtian age (Clift et al. 1999), and are overlain by the Chogdo formation which comprises sand/silt stones and mud stones (figure 1B). The Chogdo formation is overlain by a dark blackish coloured Nummulitic 
limestone of the late Palaeocene age (Clift et al. 1999). The Jurutze, Sumdo, Chogdo and Nummulitic limestone formations from the Zanskar Gorge (figure 1B) are much similar to the Miru formation (figure 1C) (Henderson et al. 2011) of the LMU section and also jointly referred to as the Tar Group in this study. The shale-bearing lacustrine coarse grain sediments of the Nurla formation were deposited over the Nummulitic limestone (Garzanti and Van Haver 1988) of the Tar Group. The Nurla formation is overlain by the basal conglomerate and alluvial sediments (red shale and sand/silt stones) of the Choksti formation (Clift et al. 2001). The Choksti formation is overlain by the Nimmu formation (Garzanti and Van Haver 1988). The Nurla, Choksti and Nimmu formations of the Zanskar Gorge (figure 1B) are similar to the Gunmaru La, Artsa, Rong, Umlung and Upshi formations (figure 1C) (Henderson et al. 2011) of the LMU section and are jointly referred to as the Indus Group in this study. The geological settings of the studied sections are comparatively summarised in table 1 .

The deposition age of the marine sediments of the Nurla and Tar Group is >46.1 Ma (Clift et al. 2001; Henderson et al. 2010a, b). The Choksti formation is nearly equivalent to the Gunmaru La and Artsa formations showing mixed signature of marine and terrestrial deposition at $\sim 46.1$ Ma (Searle 1986; Garzanti et al. 1987; Henderson et al. 2010a, b). The alluvial sediments of the Indus Group from the northern side of IBSRs were deposited between 23.7 and $6.11 \pm 2.3 \mathrm{Ma}$ (Clift et al. 2002a; Henderson et al. 2010a,b). Based on the nature of the sediments deposited, IBSRs are subdivided into three types in the present study. (i) Type-I rocks: formed by the alluvial sediments derived from the Ladakh batholith in the Indus group; (ii) Type-II rocks: formed by marine and alluvial sediments, which covered half of the Choksti formation at the base, Gunmaru La and Artsa formations and (iii) TypeIII rocks: marine in nature represented by the Tar group of rocks. It was observed in the study area that siliceous and calcareous deformed veins are omnipresent in the IBSRs of ITSZ (see figure 2).

\section{Vein morphology and petrography}

Very thin to thick (2 $\mathrm{mm}$ to a few centimetres) veins of quartz and calcite are ubiquitously present in the ITSZ. The veins show random dissemination and are classified into three categories on the basis of the mode of occurrence: (i) bounding-neck veins, (ii) network veins and (iii) fault-filling veins.

The bounding-neck veins are crosscut by faultrelated deformation structures. These veins were formed prior to the development of the fault zone (Yamaguchi et al. 2012). The network and the fault filling veins are mutually cross-cutting (figure 2). Several previous studies also suggested similar sets of crosscutting extensional and shear cracks, interpreted to have formed in response to fluctuations in fluid pressure during seismic cycles (i.e., fault-valve behaviour (Sibson et al. 1988)). The majority $(\geq 90 \%)$ of the fault-filling veins were noticed in the study area. These fault/fracture filling veins were developed along the weak planes such as fault, fracture and bedding plane, suggesting rapid invasion along the weak planes (fault, fracture and bedding plane). It also reveals that the fault/fracture filling veins may have formed during the collapse process of dilatational run within a system (Sibson 1986; Cox 1995; Yamaguchi et al. 2012). These veins are deformed and oriented along the associated host rocks (mud/ silt stone). The orientation and deformation pattern of the veins are very similar to the associated host rocks suggesting that veins may have deformed along with the IBSR and formed prior to the deformation of the study area. The field relation suggests that the vein forming fluid may have leached out from the associated host rocks due to diagenesis and metamorphism of the IBSRs. These vein forming fluids may have intruded into the weak planes of the IBSRs and formed a fault-filling network and sigmoidal veins. The minor faults and vein displacement due to the faulting were also observed in the field. These fault-filling calcite veins preserve the evidence of their source and fluid composition which migrates through the weak plane (Dietrich et al. 1983; Gao et al. 1992). The occurrence of network and bounding-neck veins are very less $(<5 \%)$ or negligible.

The microstructure of quartz and calcite is an indicator of the deformation temperature (Vernon 1981; Stipp et al. 2002, 2010; Ferrill et al. 2004). The calcite twinning shows variations in width from very thin to thick (figure $3 \mathrm{~A}-\mathrm{C}$ ), with curved and oval shapes, indicating the deformation temperature in the range from $170^{\circ}$ to $200^{\circ} \mathrm{C}$ (Burkhard 1993; Ferrill et al. 2004). Thin twins of calcite are transformed into the tabular thick twinning with increasing temperature up to $\sim 250^{\circ} \mathrm{C}$ 
Table 1. Stratigraphical succession of NC (figure 1B) and LMU (figure 1C) sections according to (Henderson et al. 2010b, 2011) and Kharya (2015).

\begin{tabular}{|c|c|c|c|c|c|c|}
\hline & \multirow[t]{2}{*}{$\begin{array}{c}\text { Stratigraphica } \\
\text { Age }\end{array}$} & \multirow[t]{2}{*}{ Group } & \multirow{2}{*}{\multicolumn{2}{|c|}{$\begin{array}{c}\text { NC Section } \\
\text { (Figure 1b) } \\
\text { (Henderson et al., 2010b) }\end{array}$}} & \multicolumn{2}{|c|}{$\begin{array}{c}\text { LMU Section } \\
\text { (Figure 1c) } \\
\text { (Henderson et al., } \\
\text { 2011) }\end{array}$} \\
\hline & & & & & North & South \\
\hline $\begin{array}{l}\text { Asian } \\
\text { Margin }\end{array}$ & Early Tertiary & \multicolumn{5}{|c|}{ Ladakh Plutonic Complex } \\
\hline \multirow{11}{*}{ 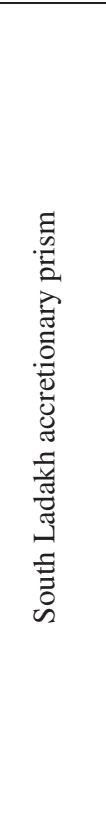 } & \multirow{3}{*}{ 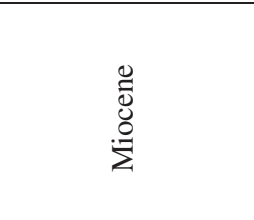 } & \multirow{7}{*}{ 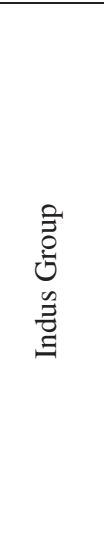 } & \multirow{2}{*}{$\underset{\mathrm{g}}{\vec{\Xi}}$} & Upper Nimu & Upshi & \multirow{3}{*}{ Rong } \\
\hline & & & & Lower Nimu & \multirow[b]{2}{*}{ Umlung } & \\
\hline & & & \multirow{4}{*}{$\begin{array}{l}: \overrightarrow{0} \\
\frac{y}{0} \\
\frac{1}{0}\end{array}$} & $\begin{array}{c}\text { Upper } \\
\text { Sandstone }\end{array}$ & & \\
\hline & \multirow{4}{*}{ 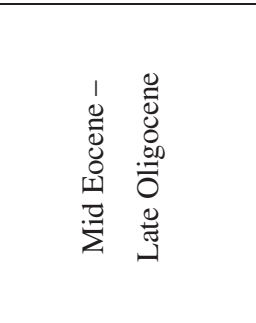 } & & & $\begin{array}{c}\text { Middle } \\
\text { Sandstone }\end{array}$ & Artsa & \multirow{3}{*}{ 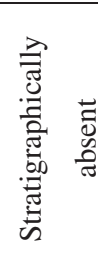 } \\
\hline & & & & Red Shale & \multirow[b]{2}{*}{ Gunmaru La } & \\
\hline & & & & $\begin{array}{c}\text { Basal } \\
\text { Conglomerate }\end{array}$ & & \\
\hline & & & \multicolumn{2}{|c|}{ Nurla } & \multirow{5}{*}{\multicolumn{2}{|c|}{ Miru }} \\
\hline & \multirow{3}{*}{ 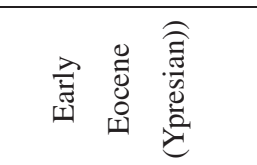 } & \multirow{4}{*}{ 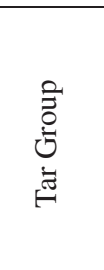 } & Numr & c Limestone & & \\
\hline & & & & gdo & & \\
\hline & & & & ndo & & \\
\hline & $\begin{array}{l}\text { Mid Cretaceuous- } \\
\text { Early Eocene }\end{array}$ & & & utze & & \\
\hline \multirow{3}{*}{ 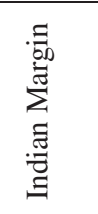 } & Mid Cretaceous & \multicolumn{3}{|c|}{ Khalsi Limestone } & \multicolumn{2}{|c|}{$\begin{array}{c}\text { Stratigraphically } \\
\text { absent }\end{array}$} \\
\hline & Cretaceous & \multicolumn{3}{|c|}{ Nindam } & \multicolumn{2}{|c|}{ Lato } \\
\hline & Triassic-Jurassic & \multicolumn{5}{|c|}{ Lamayuru } \\
\hline
\end{tabular}

(Burkhard 1993; Ferrill et al. 2004). The calcite twinning gets curved to an oval shape with a narrow end towards the grain boundary due to an increase in the strain rate at about $300^{\circ} \mathrm{C}$ (Vernon 1981). Similarly, the microstructures observed in the quartz grains show a bulging phenomenon, subgrain development and grain boundary migration in this study. The sub-grains are developed along the large grain boundary due to the micro-crack arrays between $250^{\circ}$ and $300^{\circ} \mathrm{C}$ (Tullis and Yund 1985). Bulging is observed along the sutured grain boundary with triple junction (figure 3D), suggesting a temperature range of $300-350^{\circ} \mathrm{C}$ (Stipp et al. 2002, 2010). With the increasing temperature, the grain boundary migration is developed in quartz grains at about $350-400^{\circ} \mathrm{C}$. The sub-grains were also noticed at $>400^{\circ} \mathrm{C}$ within the quartz grains (figure 3F) (Stipp et al. 2002, 2010). The microstructures of the quartz and calcite veins revealed their deformation temperatures between $170^{\circ}$ and $400^{\circ} \mathrm{C}$ (figure $3 \mathrm{~A}-\mathrm{F}$ ) (Vernon 1981; Tullis and Yund 1985; Burkhard 1993; Stipp et al. 2002; Ferrill et al. 2004, 2010).

\section{Analytical techniques}

\subsection{Trace elemental abundances}

The trace elemental abundances in the calcite and quartz phases were measured in the solution mode 

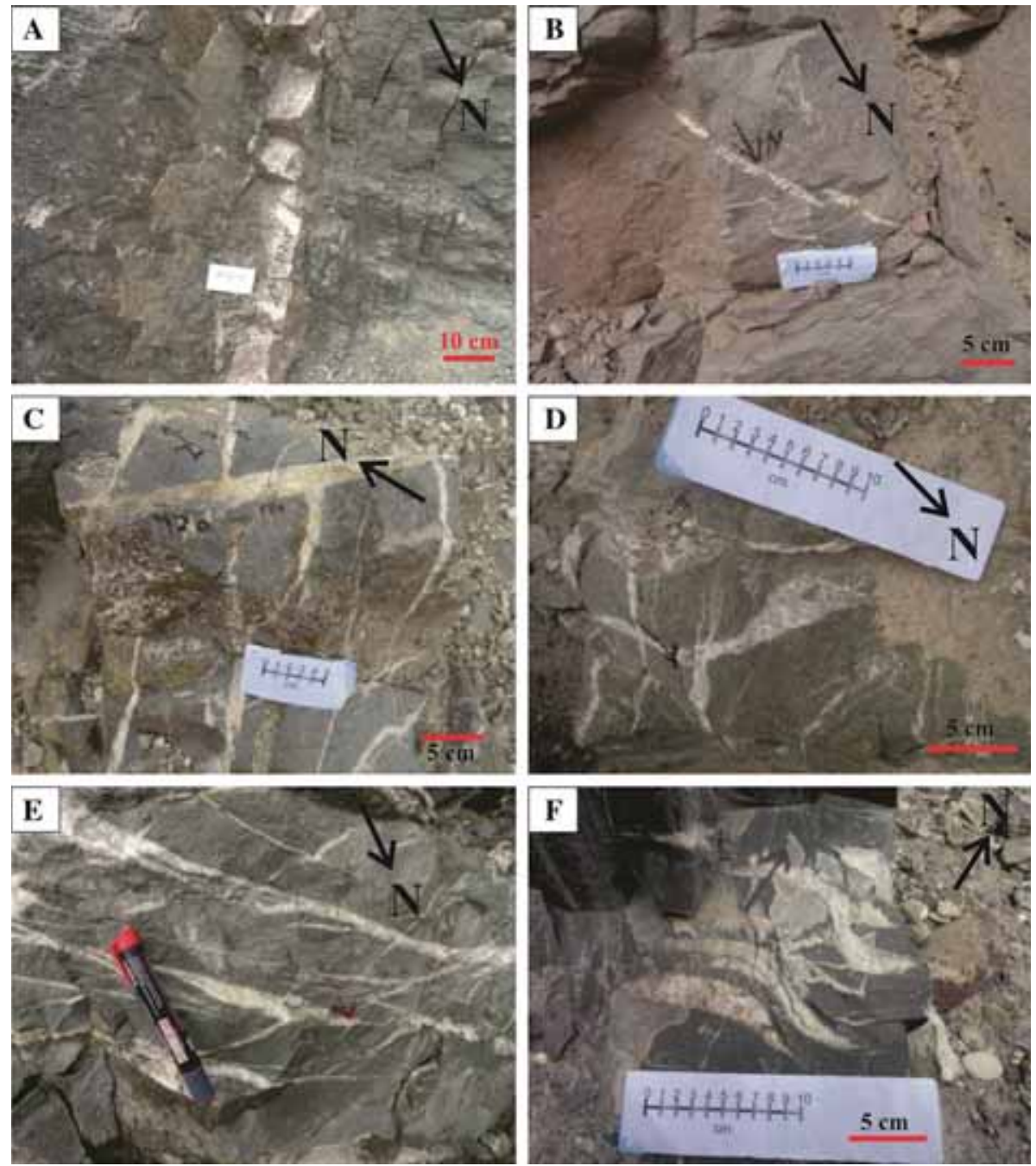

Figure 2. Field photographs of quartz and calcite veins from the NC and the LMU sections of ITSZ. (A and B), Fault-filling veins; (C-E) network veins; $(\mathbf{F})$ sigmoidal veins. The vein thickness is between a few millimetres and $2 \mathrm{~cm}$.

from pure mineral separates using quadrupole inductively coupled plasma mass spectrometry (Q-ICP-MS) at Wadia Institute of Himalayan Geology (WIHG), Dehradun, India. International standards were used for calibration, and for QA/QC purposes, SGR-1 and JDo-1, for calcite/ carbonate and JG-2, GH and MAG-1 were used for the quartz samples. The physical parameters and analytical protocols described by Ahmad et al. (2008); Khanna et al. (2009) and Mukherjee et al. (2014) were adopted in this study. The raindrop size distribution of REE and trace elements is approximately $3 \%$.

\subsection{Stable isotopic analysis}

Stable isotopic analysis $\left(\delta^{13} \mathrm{C}\right.$ and $\delta^{18} \mathrm{O}$ ratios $)$ of calcite was carried out in the stable isotope laboratory at WIHG, Dehradun, India, using a gas source, continuous flow-isotope ratio mass spectrometer (CF-IRMS) of Thermo Fisher Scientific, Delta V plus model through gas bench II, using the protocol given by Paul and Skrzypek (2007). The accuracy and precision of the standardization technique for the analysis of the carbon and oxygen isotopes in this study were determined by analysing the isotopic ratio of standards from different laboratories (WIHG and IIT Kharagpur) and the international carbonate standard of the International Atomic Energy Agency, NBS-18 (carbonatite). The precision of the carbon and oxygen isotope ratio measurements in the carbonate phase is $\pm 0.1 \%$ for both $\delta^{13} \mathrm{C}$ and $\delta^{18} \mathrm{O}$. The $\delta^{13} \mathrm{C}$ value is presented in Vienna PeeDee belemnite (VPDB) and the $\delta^{18} \mathrm{O}$ value, in Vienna standard mean ocean water (VSMOW). 

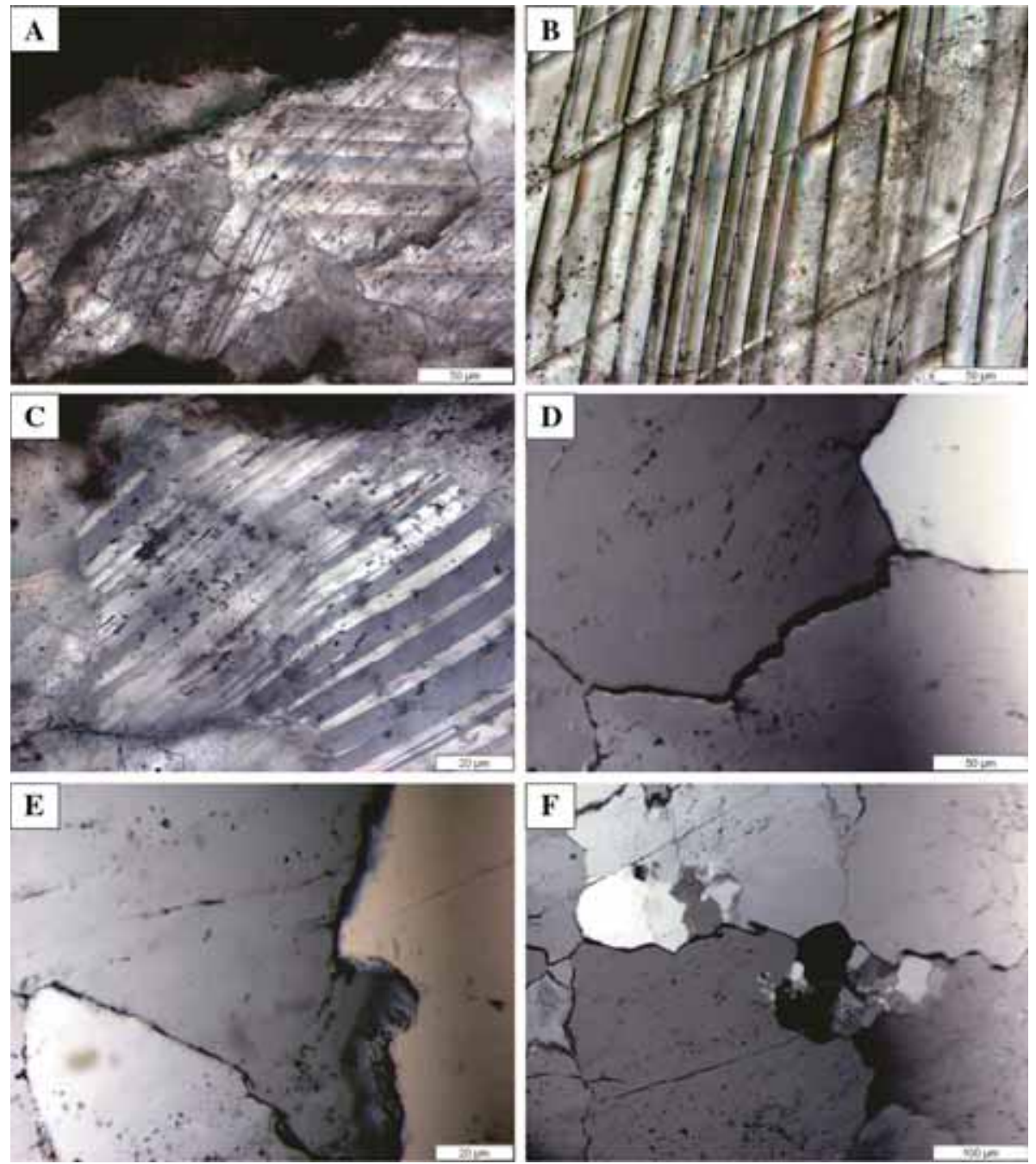

Figure 3. Microphotographs of quartz and calcite veins present in the study area. (A-C) Calcite showing thin-to-thick twinning pattern, (D) triple junction in quartz, (E) bulging in quartz, and (F) sub-grains developed within the quartz grains.

\subsection{Strontium (Sr) isotopic analysis}

Strontium (Sr) isotopic analysis in calcite minerals was carried out at the Physical Research Laboratory (PRL), Ahmedabad, India, using Neptune MC-ICPMS of Thermo Fisher Scientific. The isotopic ratios were measured on unspiked leached calcite vein samples. The chemical process for the separation of $\mathrm{Sr}$ from the samples was adopted from Rai and Singh (2007). In this procedure, $0.1 \mathrm{~g}$ powdered calcite vein samples were dissolved in $5 \%$ acetic acid. The leached samples were dried at $110^{\circ} \mathrm{C}$ (open digestion) and separated from the residual. Residuals were dissolved in $250 \mu \mathrm{l}$ of $3 \mathrm{~N} \mathrm{HNO}_{3}$. Prior to loading the sample, Sr-specific resin of Eichrom ${ }^{\circledR}$ was preconditioned by passing $3 \mathrm{~N} \mathrm{HNO}_{3}$. The dissolved residual was passed through the pre-conditioned Eichrom ${ }^{\circledR}$ Sr-specific resin. The Eichrom ${ }^{\circledR}$ Sr-specific resin has the capacity to hold Sr only; therefore, the other elements can easily be removed from the resin by passing $1.5 \mathrm{ml}\left(0.5 \mathrm{ml}\right.$ three times) of $3 \mathrm{~N} \mathrm{HNO}_{3}$. Pure Sr fraction was collected in a Savillex ${ }^{\circledR}$ Teflon vial after the addition of Milli-Q water as the eluent to the column. This $\mathrm{Sr}$ fraction was dried at $110^{\circ} \mathrm{C}$ (open digestion) and redissolved in $0.4 \mathrm{~N} \mathrm{HNO}_{3}$ for isotopic measurements by MC-ICPMS under standard instrumental conditions. The Sr isotopic composition of the calcite veins was determined by the following procedure as described by Goswami et al. (2012). The $\mathrm{Sr}$ isotopic ratio was measured by using Neptune MC-ICP-MS at the PRL using the static multi-collection mode (Goswami et al. 2012). Instrumental mass fractionation was corrected using an exponential law with 0.1194 for ${ }^{86} \mathrm{Sr} /{ }^{88} \mathrm{Sr}$. The $\mathrm{Rb}$ contribution was corrected 
by the natural abundance of ${ }^{85} \mathrm{Rb} /{ }^{87} \mathrm{Rb}$, though the amount of ${ }^{85} \mathrm{Rb}$ was negligible in all samples. SRM987 standard was run with every set of samples which yielded an ${ }^{87} \mathrm{Sr} /{ }^{86} \mathrm{Sr}$ ratio of 0.710270 $\pm 0.000018(1 \sigma, n=7)$. The procedural blank for Sr during measurement was less than $1 \mathrm{ng}$ and the total Sr analysed for the samples by Q-ICPMS was always 3-4 orders of magnitude higher than the blank. The internal precision $\left(2 \sigma_{\mu}\right)$ of these measurements was better than $0.002 \%$.

\subsection{The lead $(\mathrm{Pb})$ isotopic analysis}

The lead $(\mathrm{Pb})$ isotopic analysis has been carried out at the Department of Geological Sciences, University of Cape Town, Rondebosch, South Africa, using $\mathrm{Nu}$ instruments of NuPlasma HR. The chemical procedures given by Folling et al. (2000) were used for $\mathrm{Pb}$ isotopic determination. One gram powdered calcite vein sample was dissolved in $1 \mathrm{~N}$ acetic acid by adding $3-5 \mathrm{ml}$ in multiple steps until a slight stoichiometric excess (ca. $20 \mathrm{ml}$ ) was reached. The dissolved samples were kept for open digestion at $30-50^{\circ} \mathrm{C}$ for about $48 \mathrm{hr}$ until the reaction was accomplished. The residue fractions were washed and centrifuged three times with Milli-Q (deionised) water to separate the carbonate fraction. The separated carbonate fractions were dried and redissolved in a 4:1::HF: $\mathrm{HNO}_{3}$ mixture and placed on a hot plate at $70^{\circ} \mathrm{C}$ for $2-4$ weeks for close digestion. The redissolved (with a $4: 1:: \mathrm{HF}: \mathrm{HNO}_{3}$ mixture) separated carbonate fraction was dried. This dried fraction was again dissolved in $5 \mathrm{ml}$ of $6.2 \mathrm{M} \mathrm{HCl}$ to prepare an unspiked aliquot of the carbonate sample. The unspiked aliquots were again dried and taken up in 0.5 $\mathrm{M} \mathrm{HBr}$. The unspiked aliquots were passed twice through $2.5 \mathrm{ml}$ Teflon ion exchange columns containing $0.5 \mathrm{ml}$ anion exchange resin of BioRad ${ }^{\circledR}$ AG 1-X8 to extract $\mathrm{Pb}$, which was eluted with $0.5 \mathrm{M} \mathrm{HNO}_{3}$. The extracted $\mathrm{Pb}$ was analysed with MC-ICPMS. Pb was loaded on single Re filaments with silica gel $10 \mathrm{ml}$ phosphoric acid $\left(\mathrm{H}_{3} \mathrm{PO}_{4}\right)$ and run under static mode on a multi-collector mass spectrometer. The $\mathrm{Pb}$ isotopic ratio was corrected for $\mathrm{Hg}$ interference and mass fractionation (Will et al. 2010). The correction for instrumental mass fractionation was carried out using the exponential law and a ${ }^{205} \mathrm{Tl} /{ }^{203} \mathrm{Tl}$ value of 2.3889 (Thirlwall 2002). The $\mathrm{Pb}$ isotopes were analysed interspersed with the NIST SRM981 standard. All Pb isotopic measurements are reported here within an error of $2 \sigma$. Most of the $\mathrm{Pb}$ was run for 200 ratios in blocks of 20 single measurements with stable beam intensities.

\section{Results}

\subsection{REE geochemistry}

REE geochemistry of quartz and calcite minerals was carried out on pure mineral separated from the veins. The REE patterns of quartz and calcite minerals from the studied sections show high light rare earth element (LREE) and low heavy rare earth element (HREE) or nearly a flat REE pattern with positive (+ve) Eu anomaly (figure 4).

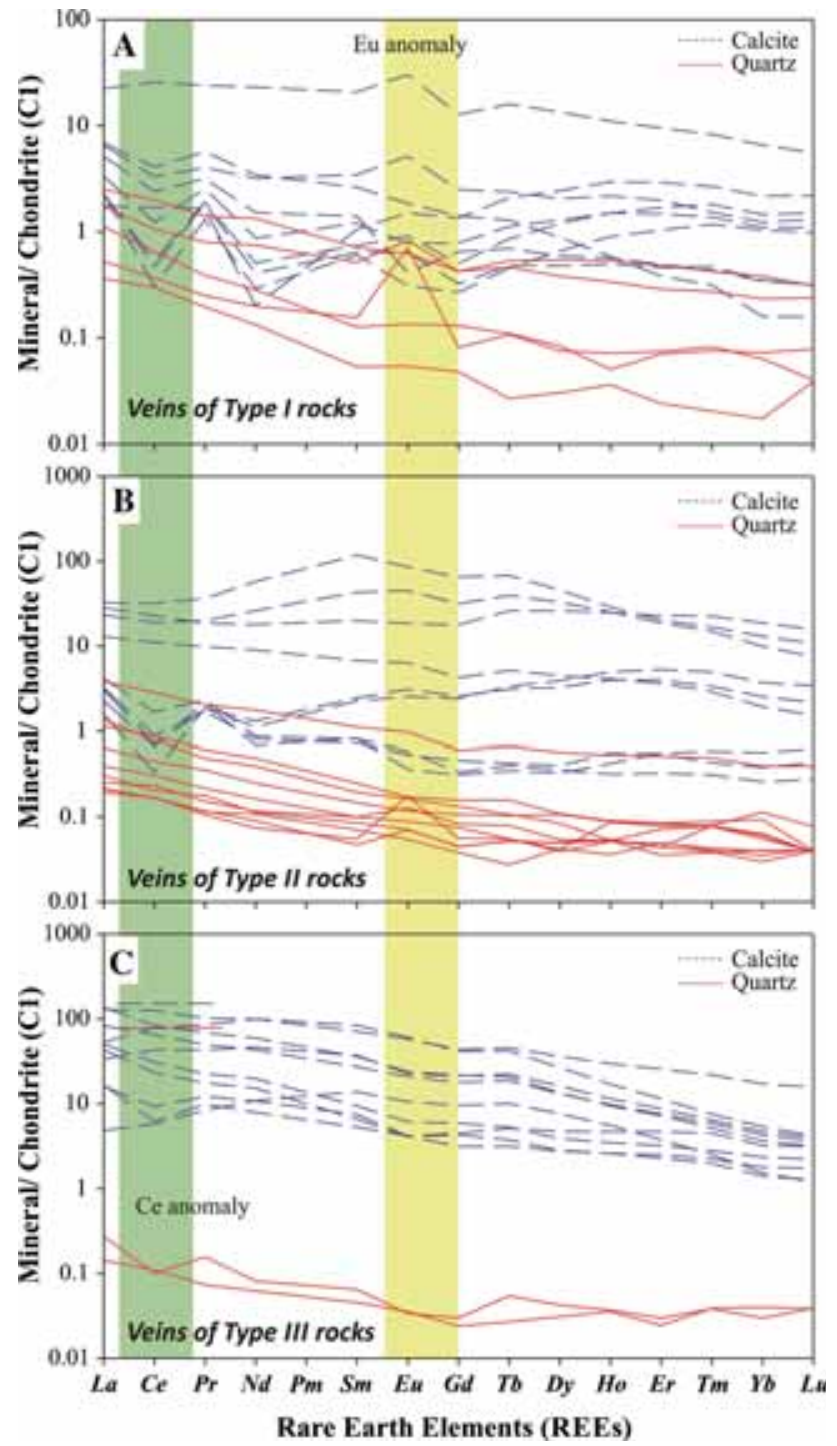

Figure 4. Co-paired quartz and calcite vein of REE plots of IBSRs. (A) REE plots of veins present in type I (terrestrial) rocks, (B) REE plots of veins present in type II (terrestrial + marine) rocks, and (C) REE plots of veins present in type III (marine) rocks. 
Table 2. Distribution coefficient (KD CC/Qtz) of REEs between calcite and quartz.

\begin{tabular}{|c|c|c|c|c|c|c|c|c|c|c|c|c|c|}
\hline \multicolumn{14}{|c|}{ Average distribution coefficient for REEs (calcite/quartz) } \\
\hline $\mathrm{La}$ & $\mathrm{Ce}$ & $\operatorname{Pr}$ & $\mathrm{Nd}$ & $\mathrm{Sm}$ & $\mathrm{Eu}$ & $\mathrm{Gd}$ & $\mathrm{Tb}$ & Dy & Но & Er & $\mathrm{Tm}$ & $\mathrm{Yb}$ & $\mathrm{Lu}$ \\
\hline 48 & 46 & 62 & 64 & 131 & 102 & 93 & 123 & 103 & 95 & 88 & 52 & 61 & 54 \\
\hline \multicolumn{4}{|c|}{ LREE } & \multicolumn{5}{|c|}{ MREE } & \multicolumn{5}{|c|}{ HREE } \\
\hline
\end{tabular}

Table 3. Various isotopic distributions of calcite veins in the study area.

\begin{tabular}{|c|c|c|c|}
\hline & South & & North \\
\hline & \multicolumn{3}{|c|}{ Veins hosted by } \\
\hline & $\begin{array}{c}\text { Marine sediments } \\
\text { (Type-III) }\end{array}$ & $\begin{array}{c}\text { Mixed sediments } \\
\text { (Type-II) }\end{array}$ & $\begin{array}{c}\text { Terrestrial sediments } \\
\text { (Type-I) }\end{array}$ \\
\hline$\delta^{13} \mathrm{C} \%$ (VPDB) & -9.9 to -1.0 & -14.3 to -3.8 & -12.8 to -0.8 \\
\hline $\mathrm{SD}: \pm 0.1 \%$ & & & \\
\hline$\delta^{18} \mathrm{O} \%$ (VSMOW) & $17.3-24.9$ & $11.1-17.1$ & $5.7-14.3$ \\
\hline SD: $\pm 0.1 \%$ & & & \\
\hline $\begin{array}{l}{ }^{87} \mathrm{Sr} /{ }^{86} \mathrm{Sr} \\
( \pm 2 \sigma)\end{array}$ & $0.7071-0.7081$ & $0.7062-0.7099$ & $0.7056-0.7062$ \\
\hline $\begin{array}{l}{ }^{208} \mathrm{~Pb} /{ }^{204} \mathrm{~Pb} \\
( \pm 2 \sigma)\end{array}$ & 38.9894 & $38.8309-38.9921$ & $38.9428-39.0374$ \\
\hline $\begin{array}{l}{ }^{207} \mathrm{~Pb} /{ }^{204} \mathrm{~Pb} \\
( \pm 2 \sigma)\end{array}$ & 15.6649 & $15.6402-15.6709$ & $15.6694-15.6816$ \\
\hline $\begin{array}{l}{ }^{206} \mathrm{~Pb} /{ }^{204} \mathrm{~Pb} \\
( \pm 2 \sigma)\end{array}$ & 18.6444 & $18.5776-18.6924$ & $18.6066-18.6627$ \\
\hline
\end{tabular}

The REE of the coexisting quartz and calcite minerals were compared on a pair basis; it shows a high distribution coefficient $(>40)$ of REEs for calcite/quartz, irrespective of the net REE budget of the initial hydrothermal solution. The partition coefficients for CC/Qtz (calcite/quartz) are much higher for MREEs as compared to the HREEs and LREEs (table 2).

\section{$5.2 C$ and $O$ stable isotope data}

The $\mathrm{C}$ and $\mathrm{O}$ stable isotope data of carbonate veins are summarised in table 3 and shown in figure 5, excluding outliers and the detailed data set in the Appendix. The $\delta^{13} \mathrm{C}$ values of calcite veins hosted by the terrestrial sediments (TypeI) are in the range of $-12.8 \%$ to $-0.8 \%$ VPDB (with some outliers) and $\delta^{18} \mathrm{O}$ values from $+5.7 \%$ to $+14.3 \%$ VSMOW. The $\delta^{13} \mathrm{C}$ and $\delta^{18} \mathrm{O}$ values of veins hosted by mixed (terrestrial and marine or Type-II) sediments are in the range of $-14.3 \%$ to $-3.8 \%$ VPDB (with some outliers) and $+11.1 \%$ to $+17.4 \%$ VSMOW, respectively. The veins hosted by marine (Type-III) sediments are enriched in the $\delta^{13} \mathrm{C}$ and $\delta^{18} \mathrm{O}$ ratio ranging from $-9.9 \%$ to $1.0 \%$ VPDB with an outlier of $-13.3 \%$ VPDB and $+17.3 \%$ to $+24.9 \%$ VSMOW, respectively. The $\delta^{13} \mathrm{C}$ values of Type$\mathrm{I}$ veins are depleted. The $\delta^{13} \mathrm{C}$ and $\delta^{18} \mathrm{O}$ ratios of veins hosted by Type-II rocks are scattered between mantle/magmatic and ophicarbonate fields and lies within the mixing mantle-marine hyperbola (Nummulitic limestone). The $\delta^{13} \mathrm{C}$ and $\delta^{18} \mathrm{O}$ values of Type-III veins are near the marine field.

\subsection{Sr isotopic composition}

The Sr isotopic composition of the samples from the studied sections is summarised in table 3 with $2 \sigma$ standard deviation (SD). The Sr isotopic ratios $\left({ }^{87} \mathrm{Sr} /{ }^{86} \mathrm{Sr}\right)$ of calcite veins hosted by the terrestrial (Type-I) sediments are in the range from 0.7056 to 0.7062 (figure 6 ). The $\mathrm{Sr}$ isotope ratio 


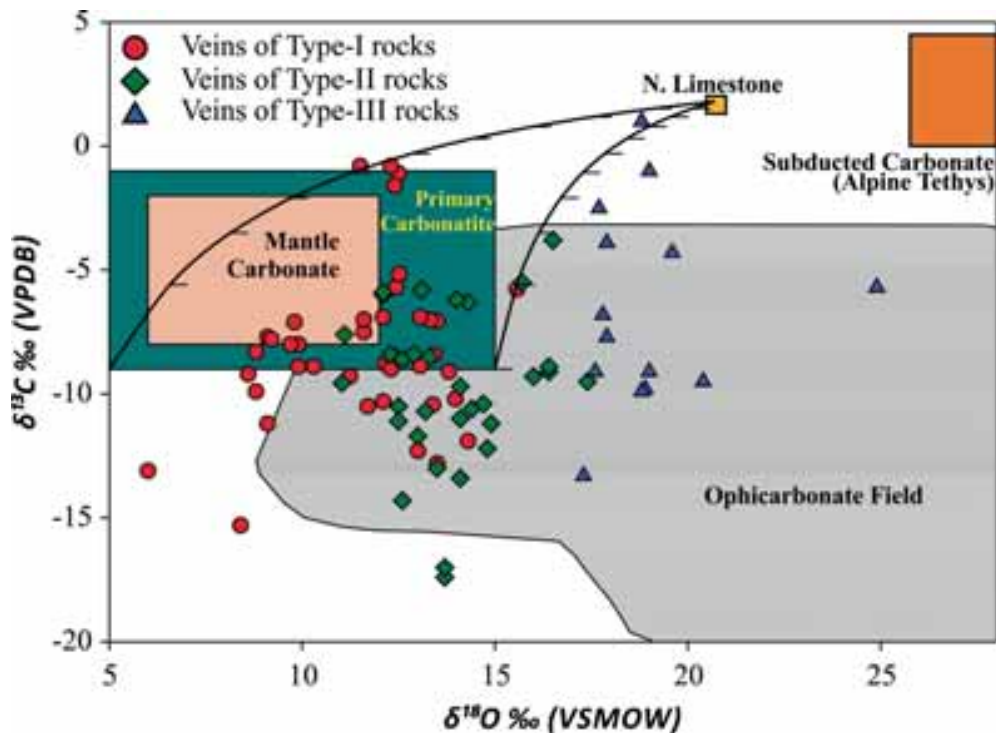

Figure 5. Correlation plot of $\delta^{13} \mathrm{C} \%$ (V-PDB) vs. $\delta^{18} \mathrm{O}^{0} \%$ (V-SMOW) from the two sections of the IBSR. Data source for the mantle carbonate field (Taylor et al. 1967), primary carbonatite field (Ray and Ramesh 2006), Ophicarbonates (Perkins et al. 2006), subducted/alpine tethys carbonate (Menegatti et al. 1998).

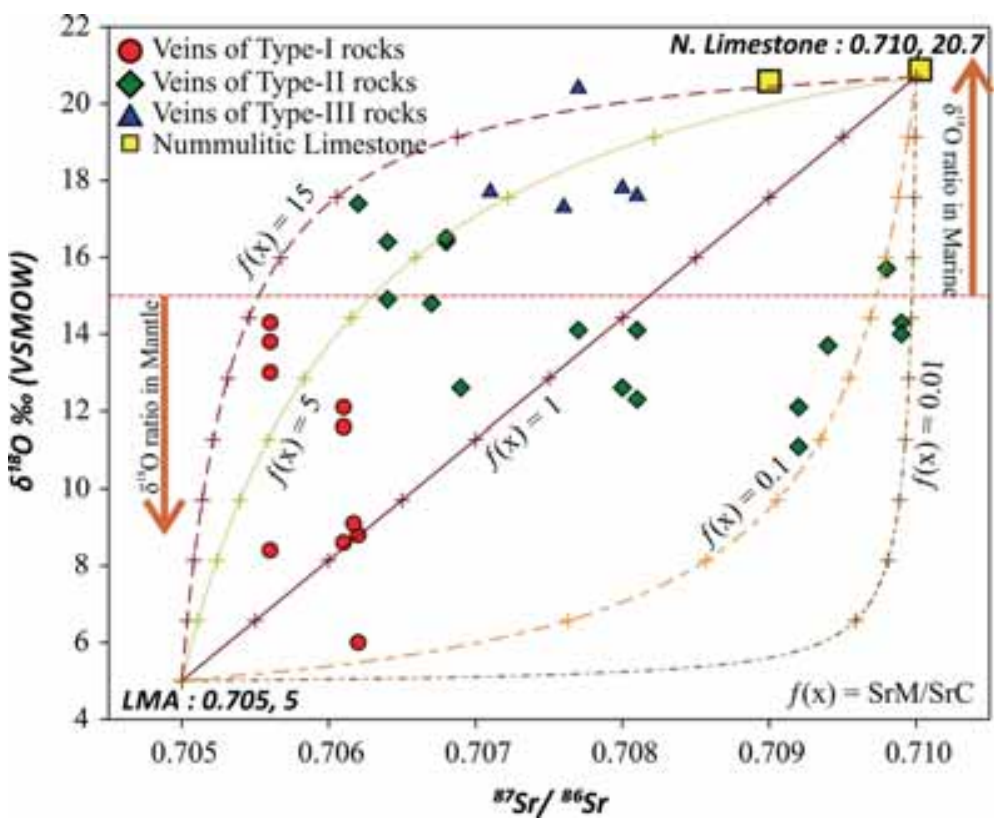

Figure 6. Mixing model between two end members (mantle and marine) of ${ }^{87} \mathrm{Sr} /{ }^{86} \mathrm{Sr}$ and $\delta^{18} \mathrm{O}$ indicates the mixing of the subducted sediments with mantle fluid. $\mathrm{SrM}=$ strontium in mantle and $\mathrm{SrC}=$ strontium in marine. Mantle value is taken from Hart (1984, 1988), White and Hofmann (1982) and Ray and Ramesh (2006). Marine value is taken from Menegatti et al. (1998).

$\left({ }^{87} \mathrm{Sr} /{ }^{86} \mathrm{Sr}\right)$ of the calcite veins present in the mixture of terrestrial and marine (Type-II) sediments varies from 0.7062 to 0.7099 (figure 6), and that of the calcite veins hosted by marine (Type-III) sedimentary rocks are in the range from 0.7071 to 0.7081 (figure 6). The $\mathrm{Sr}$ isotopic composition of Type-III veins hosted by marine sediments indicates the age ( $\mathrm{Sr}$ isotope stratigraphy) of veins between 55 and $27 \mathrm{Ma}$ (McArthur et al. 2012).

\subsection{Ranges of various lead $(\mathrm{Pb})$ isotopic ratios}

The ranges of various lead $(\mathrm{Pb})$ isotopic ratios are presented in table 3 . The bivariant plots 

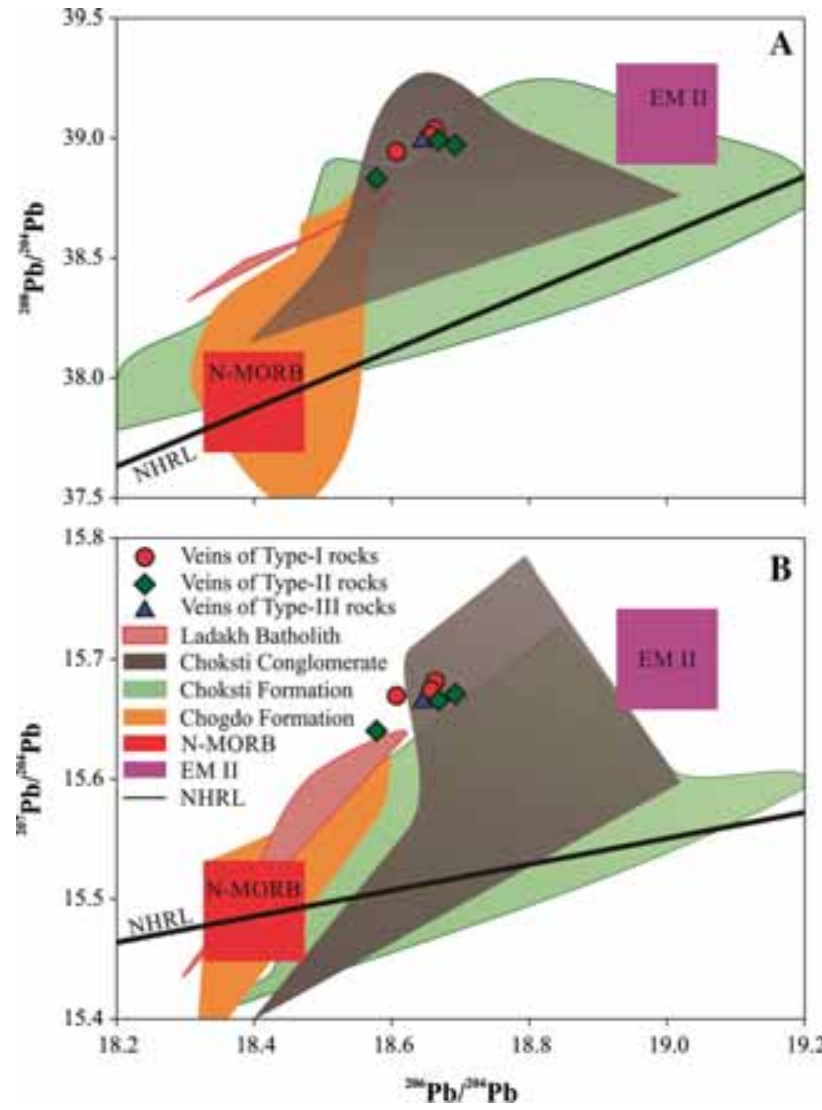

Figure 7. Correlation plots and mixing model between end members (MORB and EM II) of (A) ${ }^{208} \mathrm{~Pb} /{ }^{204} \mathrm{~Pb}$ vs. ${ }^{206} \mathrm{~Pb} /{ }^{204} \mathrm{~Pb}$ and $(\mathbf{B}){ }^{207} \mathrm{~Pb} /{ }^{204} \mathrm{~Pb}$ vs. ${ }^{206} \mathrm{~Pb} /{ }^{204} \mathrm{~Pb}$, from the study area. Data sources for MORB and EM II (Enrich Mantle II) are taken from Hart (1988).

${ }^{208} \mathrm{~Pb} /{ }^{204} \mathrm{~Pb}$ vs. ${ }^{206} \mathrm{~Pb} /{ }^{204} \mathrm{~Pb}$ and ${ }^{207} \mathrm{~Pb} /{ }^{204} \mathrm{~Pb}$ vs. ${ }^{206} \mathrm{~Pb} /{ }^{204} \mathrm{~Pb}$ are shown in figure $7(\mathrm{~A}$ and $\mathrm{B})$, respectively.

\section{Discussion}

Calcite veins were formed in the low-grade metamorphosed (up to lower greenschist facies) sediments of IBSRs in the Indus Tsangpo suture zone. The compositional changes recorded in trace elements and REEs were considered as a proxy for tracking fluid sources during the terminal stages of the India-Asia collision. The geochemical results reveal two types of fluids involved in the formation of veins: (i) marine fluid and (ii) magmatic fluid. The marine fluid possibly sourced from (i) the marine carbonate of Tethyan Himalayas and (ii) leached out from associated Type-I rocks. Whereas the mantle/magmatic fluids were probably derived from the (i) upper mantle, (ii) mineral dehydration from the oceanic crust (mafic and ultramafic rocks of oceanic plate)/ ophicarbonates and (iii) leached out from the associated Type-III rocks.

The aforesaid alternatives of fluid sources are tested and appropriately explained in the following sections.

\subsection{The REE geochemistry}

The REE geochemistry of veins hosted by Type-I rocks and few Type-II rocks in IBSRs shows positive (+ve) Eu anomaly indicating a relatively reducing environment (Martinez-Ruiz et al. 1999) of fluid source (i.e., mantle/magmatic system). The $\mathrm{Eu}^{2+}$ is more readily incorporated in calcite as compared to other REEs in +3 state, giving rise to + ve Eu anomaly. Veins of Type-II and TypeIII lithounits show - ve Ce anomaly, indicating its marine affinity to the fluid source.

The LREE/MREE is a function of the extent of REE fractionation and their origin (crustal vs. mantle/magmatic). Similarly, Eu/Eu* is also an indicator of the source - plagioclase-free (mantle/ magmatic; for $\mathrm{Eu}^{+\mathrm{ve}}$ anomaly) or plagioclasebearing (crustal) fluid source with or without positive Eu-anomaly, respectively (Castor and Hedrick 2006). The LREE/MREE (La/Gd) with Eu/Eu* is $>1$ in the veins of Type-I and Type-II lithounits suggesting mantle or magmatic fluid nature. However, a few vein samples from Type-II and Type-III lithounits have anomaly as $<1$ points towards marine-related sources. The REE geochemistry indicates veins with characteristics similar to those of lithounits and therefore appears to be controlled by the element exchange with the lithounits of IBSRs. The data indicate that vein fluid was leached out from the associated host rocks, rather than the other external sources. The pattern of REEs of Type-I veins advocates a magmatic source of fluid, whereas the pattern of REEs of TypeIII veins suggests the marine fluid source. The host rock for Type-I vein fluid is terrestrial siliciclastics derived from the Ladakh magmatic arc, which is magmatic in nature and the Type-III veins are hosted by the Tethyan sedimentary sequence with distinct protoliths deposited under marine conditions, whereas, TypeII veins were formed in the mixed (terrestrial and marine) sedimentary sequence, showing similar characteristics of the host lithounit. Therefore, the REE geochemistry indicates that fluids were probably generated from the associated host rocks. 


\subsection{Stable isotope}

Stable isotope values of calcite veins are presented in figure 5. The $\delta^{13} \mathrm{C}$ and $\delta^{18} \mathrm{O}$ values of veins for Type-I rocks of IBSRs lie mostly in the primary carbonatite/ophicarbonate field, indicating the possibility of mantle/magmatic fluid sources of veins. The depleted $\delta^{13} \mathrm{C}$ of Type-I veins may be due to the complete recrystallisation of carbonate rocks, which is evident from the presence of microstructures (figure 3). The occurrence of Type-II veins within the mixing mantle-marine hyperbola (Nummulitic limestone) indicates the enrichment of $\delta^{13} \mathrm{C}$ and $\delta^{18} \mathrm{O}$ values due to marine/subducted carbonates. The mantlemarine mixing hyperbola of stable isotopic end members indicates a mantle contribution of $\sim 70 \%$ and marine $\sim 30 \%$ in the Type-II veins. The stable isotopic values of Type-III veins are akin to the marine field and are also influenced by the magmatic fluid ( $\sim 40 \%$ in few samples). The veins of Type-III are hosted by the marine sediments (Type-III rocks) and may have formed by the leaching of carbonate from the host rocks and depletion in $\delta^{13} \mathrm{C}$ values due to the recrystallisation of the carbonates. The mantle-marine mixing hyperbola for $\delta^{13} \mathrm{C}$ and $\delta^{18} \mathrm{O}$ is drawn using the equation given by Faure (1977), where the end member value for marine carbonate is $1.8 \% \mathrm{VPDB}$, and $20.7 \%$ VSMOW for $\delta^{13} \mathrm{C}$ and $\delta^{18} \mathrm{O}$, respectively, from the Nummulitic limestone of the study area. The end member values of the mantle/magmatic field for $\delta^{18} \mathrm{O}$ are $5 \%$ and $15 \%$ VSMOW, and $-9 \%$ VPDB for $\delta^{13} \mathrm{C}$ (Ray and Ramesh 2006).

\subsection{The strontium isotope $\left({ }^{87} \mathrm{Sr} /{ }^{86} \mathrm{Sr}\right)$ ratio}

The strontium isotope $\left({ }^{87} \mathrm{Sr} /{ }^{86} \mathrm{Sr}\right)$ ratio of calcite veins indicates genetic sources of fluid. These data (table 3) show remarkable variation in various sedimentary packages (Type-I to Type-III rocks) from the north to the south. The Sr isotopic ratios of veins are enriched in the marine sedimentary package (Type-III rocks, south margin) as compared to the terrestrial sediments (Type-I rocks, northern margin). The Sr isotopic ratios (0.7056-0.7065) of Type-I veins are very similar to the adjacent Ladakh magmatic arc or host rocks 0.7036-0.7077 (Honegger et al. 1982; Weinberg and Dunlap 2000). The Sr isotopic composition of Type-II veins varies from 0.706 to 0.710 , suggesting that the fluids were derived from Type-II rocks having mixed magmatic (Type-I) and marine (Type-III) sediments. The
$\mathrm{Sr}$ isotopic composition of Type-III veins varies between 0.707 and 0.708 , close to the value 0.709 of the Nummulitic limestone of the study area. The distribution of veins for their ${ }^{87} \mathrm{Sr} /{ }^{86} \mathrm{Sr} v s$. $\delta^{18} \mathrm{O}$ ratio can be explained by the two-component mixing model (figure 6), for which end members are: (i) Ladakh magmatic arc/magmatic and (ii) marine sediments of the study area, where SrM and $\mathrm{SrC}$ refer to the $\mathrm{Sr}$ in the magmatic fluid/Ladakh magmatic arc and the marine sediments, respectively. The $f(x)=\mathrm{SrM} / \mathrm{SrC}$ is a ratio between $\mathrm{Sr}$ in magmatic and marine sediments. The $\mathrm{SrM} / \mathrm{SrC}$ ratio of $>1$ suggests $\mathrm{Sr}$ enriched mantle-like derived fluid, and the $\mathrm{SrM} / \mathrm{SrC}$ ratio of $<1$ indicates a $\mathrm{Sr}-$ depleted mantle-like derived fluid or marine fluid. The ${ }^{87} \mathrm{Sr} /{ }^{86} \mathrm{Sr}$ and $\delta^{18} \mathrm{O}$ values for magmatic fluid $0.705\left({ }^{87} \mathrm{Sr} /{ }^{86} \mathrm{Sr}\right)$ are taken from the Ladakh magmatic arc and 5\% VSMOW of primary carbonatite (Ray and Ramesh 2006), respectively, whereas ${ }^{87} \mathrm{Sr} /{ }^{86} \mathrm{Sr}$ and $\delta^{18} \mathrm{O}$ values for the marine sediment are taken as $0.7100 \%$ and $28 \%$ VSMOW (an average of Alpine tethys carbonate) from Menegatti et al. (1998), respectively. The ${ }^{87} \mathrm{Sr} /{ }^{86} \mathrm{Sr}$ and $\delta^{18} \mathrm{O}$ values of calcite veins from different lithounits are plotted in the two-component model as shown in figure 6. The Type-I veins plot mostly in the Sr-enriched mantle hyperbola $(f(x)=1-15)$, with an outlier $(2 \sigma)$ that has $>60 \%$ of fluid from a mantle-like source as contribution. The enrichment in an oxygen isotope may be due to the deformation or recrystallisation of the veins. Whereas the veins of Type-III rocks lie within the hyperbola defined by $f(x)=1$ to 0.01 , with $50-60 \%$ contribution from a marine-like fluid. The TypeII veins show a wide distribution from 0.01 to 3 in their $\mathrm{SrM} / \mathrm{SrC}$ ratios with $50-70 \%$ mantlelike fluid, with some outliers. The wide variation of the $\mathrm{SrM} / \mathrm{SrC}$ ratio in Type-II veins is due to the veins hosted by both mixed (terrestrial and marine) sediments and hence preserves both the signatures.

\subsection{The lead $(\mathrm{Pb})$ isotope}

The lead $(\mathrm{Pb})$ isotope systematics also helps in understanding the fluid provenance and discrimination between different mantle end members. The $\mathrm{Pb}$ isotopic results are presented in figure 7. All vein samples are plotted with the $\mathrm{Pb}$ isotope ratios of various lithounits of the study area. The $\mathrm{Pb}$ isotope ratios, used as a reference here, for various lithounits were obtained from Clift et al. (2002b). The $\mathrm{Pb}$ isotopic results of the vein sample lie 
within the field of existing lithounits and suggest the derivation of the vein-forming fluid from the associated host rocks.

\subsection{Geodynamic implications}

The isotope systematics of the veins reveals the nature of the fluid involved in the process of the formation of IBSRs. The formation of veins in the IBSRs is controlled by the lithology of the area. The isotopic composition of veins also varies with the lithology. The marine sediments are dominant at the southern side, separated by the Zanskar thrust from the Lamayuru formation. The northern side of IBSR comprises the terrestrial sediments, tectonically controlled by the Indus thrust and separated from the LMA. These sediments were intermixed in the middle of the studied area. The veins of the northern side (Type-I) have mantle/magmatic isotopic signature, similar to the host rock, whereas the southern side (Type-III) veins are marine in nature, and mixed (Type-II) veins are present between the mixed lithounits. These veins were probably formed by the diagenesis and metamorphism of associated host rock sediments prior to the deformation of the IBSRs.

\section{Conclusions}

Based on this study, the following conclusions may be drawn:

(i) The field relation indicates that the veins of IBSRs were deformed along with the host rocks and were formed prior to the deformation of the study area.

(ii) Quartz and calcite veins were formed during or immediately after the compaction/ sedimentation of the host rocks.

(iii) The REEs and isotope geochemistry suggest that veins are lithologically controlled.

(iv) The vein-forming fluids were sourced from the host rocks.

\section{Acknowledgements}

The authors are thankful to the Director, Wadia Institute of Himalayan Geology (WIHG), Dehradun, for the permission to publish this work. The authors are also thankful to Anil Kumar Gupta, IIT Kharagpur and S K Ghosh for his help with the improvement of the paper. We gratefully acknowledge financial support from the Department of Science \& Technology, Government of India (Grant no. SR/S4/ES-495/2009) for this work.

\section{Appendix}

Table A1. Stable and radiogenic isotopic data set of carbonate veins hosted by various lithounits of the IBSRs.

\begin{tabular}{|c|c|c|c|c|c|c|c|}
\hline \multirow[b]{3}{*}{ Veins hosted by } & \multirow{3}{*}{$\begin{array}{c}\text { Sample } \\
\text { no. }\end{array}$} & \multicolumn{2}{|c|}{$\begin{array}{l}\text { Stable isotope } \\
(\mathrm{SD}: \pm 0.1 \%)\end{array}$} & \multirow{3}{*}{$\begin{array}{c}\text { Sr isotope } \\
(\mathrm{SD}: 2 \sigma) \\
{ }^{87} \mathrm{Sr} /{ }^{86} \mathrm{Sr}\end{array}$} & \multirow{2}{*}{\multicolumn{3}{|c|}{$\mathrm{Pb}$ isotope (SD: $2 \sigma)$}} \\
\hline & & $\delta^{13} \mathrm{C}$ & $\delta^{18} \mathrm{O}$ & & & & \\
\hline & & (VPDB) & (VSMOW) & & ${ }^{208} \mathrm{~Pb} /{ }^{204} \mathrm{~Pb}$ & ${ }^{207} \mathrm{~Pb} /{ }^{204} \mathrm{~Pb}$ & ${ }^{206} \mathrm{~Pb} /{ }^{204} \mathrm{~Pb}$ \\
\hline Terrestrial sediments & $\mathrm{NC} 12 / 54$ & -8.7 & 5.7 & & & & \\
\hline Terrestrial sediments & $\mathrm{NC} 12 / 51$ & -13.1 & 6 & & 39.0098 & 15.6742 & 18.657 \\
\hline Terrestrial sediments & $\mathrm{NC} 12 / 53$ & -7.4 & 8.2 & & & & \\
\hline Terrestrial sediments & $\mathrm{NC} 12 / 52$ & -15.3 & 8.4 & 0.7056 & & & \\
\hline Terrestrial sediments & $\mathrm{NC} 12 / 47$ & -9.2 & 8.6 & 0.7061 & 38.9428 & 15.6694 & 18.6066 \\
\hline Terrestrial sediments & LMU13/5 & -8.3 & 8.8 & & & & \\
\hline Terrestrial sediments & $\mathrm{NC} 12 / 48$ & -9.9 & 8.8 & 0.7062 & 39.0374 & 15.6816 & 18.6627 \\
\hline Terrestrial sediments & LMU12/45 & -7.7 & 9.1 & & & & \\
\hline Terrestrial sediments & $\mathrm{NC} 12 / 49$ & -11.2 & 9.1 & 0.7062 & & & \\
\hline Terrestrial sediments & LMU12/46 & -7.8 & 9.2 & & & & \\
\hline Terrestrial sediments & LMU13/4 & -8 & 9.7 & & & & \\
\hline Terrestrial sediments & LMU13/3 & -7.1 & 9.8 & & & & \\
\hline Terrestrial sediments & LMU13/2 & -8 & 9.9 & & & & \\
\hline Terrestrial sediments & LMU12/44 & -8.9 & 9.9 & & & & \\
\hline Terrestrial sediments & LMU12/21 & -8.9 & 10.3 & & & & \\
\hline Terrestrial sediments & LMU12/47 & -7.2 & 10.4 & & & & \\
\hline
\end{tabular}


Table A1. (Continued.)

\begin{tabular}{|c|c|c|c|c|c|c|c|}
\hline \multirow[b]{2}{*}{ Veins hosted by } & \multirow[b]{2}{*}{$\begin{array}{c}\text { Sample } \\
\text { no. }\end{array}$} & \multicolumn{2}{|c|}{$\begin{array}{l}\text { Stable isotope } \\
(\mathrm{SD}: \pm 0.1 \%)\end{array}$} & \multirow{2}{*}{$\begin{array}{c}\text { Sr isotope } \\
(\mathrm{SD}: 2 \sigma) \\
{ }^{87} \mathrm{Sr} /{ }^{86} \mathrm{Sr}\end{array}$} & \multicolumn{3}{|c|}{$\mathrm{Pb}$ isotope (SD: $2 \sigma)$} \\
\hline & & $\begin{array}{c}\delta^{13} \mathrm{C} \\
(\mathrm{VPDB})\end{array}$ & $\begin{array}{c}\delta^{18} \mathrm{O} \\
(\mathrm{VSMOW})\end{array}$ & & ${ }^{208} \mathrm{~Pb} /{ }^{204} \mathrm{~Pb}$ & ${ }^{207} \mathrm{~Pb} /{ }^{204} \mathrm{~Pb}$ & ${ }^{206} \mathrm{~Pb} /{ }^{204} \mathrm{~Pb}$ \\
\hline Terrestrial sediments & $\mathrm{NC} 12 / 40$ & -11.9 & 14.3 & 0.7056 & & & \\
\hline Terrestrial sediments & NC13/1 & -0.8 & 11.5 & & & & \\
\hline Terrestrial sediments & NC13/1 & -0.8 & 11.5 & & & & \\
\hline Terrestrial sediments & LMU12/40 & -7 & 11.6 & & & & \\
\hline Terrestrial sediments & LMU12/22 & -7.5 & 11.6 & & & & \\
\hline Terrestrial sediments & LMU12/43 & -10.5 & 11.7 & & & & \\
\hline Terrestrial sediments & $\mathrm{NC} 12 / 45$ & -9.1 & 13.8 & 0.7056 & & & \\
\hline Terrestrial sediments & $\mathrm{NC} 12 / 39$ & -12.3 & 13 & 0.7056 & & & \\
\hline Terrestrial sediments & LMU12/41 & -6.9 & 12.1 & & & & \\
\hline Terrestrial sediments & LMU12/25 & -10.3 & 12.1 & 0.7061 & & & \\
\hline Terrestrial sediments & $\mathrm{NC} 13 / 3$ & -0.8 & 12.3 & & & & \\
\hline Terrestrial sediments & $\mathrm{NC} 13 / 3$ & -0.8 & 12.3 & & & & \\
\hline Terrestrial sediments & $\mathrm{NC} 12 / 38$ & -12.8 & 13.5 & & & & \\
\hline Terrestrial sediments & LMU12/17 & -9 & 12.3 & & & & \\
\hline Terrestrial sediments & $\mathrm{NC} 13 / 4$ & -1.6 & 12.4 & & & & \\
\hline Terrestrial sediments & $\mathrm{NC} 13 / 4$ & -1.6 & 12.4 & & & & \\
\hline Terrestrial sediments & LMU12/28 & & & 0.7061 & & & \\
\hline Terrestrial sediments & $\mathrm{NC} 13 / 2$ & -1.1 & 12.5 & & & & \\
\hline Terrestrial sediments & $\mathrm{NC} 13 / 2$ & -1.1 & 12.5 & & & & \\
\hline Mixed sediments & LMU12/11 & -10.5 & 12.5 & & & & \\
\hline Mixed sediments & $\mathrm{NC} 12 / 37$ & -11.1 & 12.5 & & & & \\
\hline Mixed sediments & LMU12/24 & -8.6 & 12.6 & 0.7069 & 38.9725 & 15.6709 & 18.6924 \\
\hline Mixed sediments & $\mathrm{NC} 12 / 35$ & -14.3 & 12.6 & 0.708 & & & \\
\hline Mixed sediments & $\mathrm{NC} 12 / 13$ & -8.4 & 12.9 & & & & \\
\hline Mixed sediments & LMU12/15 & -11.7 & 13 & & & & \\
\hline Mixed sediments & $\mathrm{NC} 12 / 20$ & -7.6 & 11.1 & 0.7092 & & & \\
\hline Mixed sediments & $\mathrm{NC} 12 / 8$ & -5.8 & 13.1 & & & & \\
\hline Mixed sediments & LMU12/23 & -10.7 & 13.2 & & & & \\
\hline Mixed sediments & LMU12/16 & -8.5 & 13.3 & & & & \\
\hline Mixed sediments & $\mathrm{NC} 12 / 9$ & -5.9 & 12.1 & 0.7092 & & & \\
\hline Mixed sediments & $\mathrm{NC} 12 / 33$ & -13 & 13.5 & & & & \\
\hline Mixed sediments & $\mathrm{NC} 12 / 36$ & -17 & 13.7 & & & & \\
\hline Mixed sediments & $\mathrm{NC} 12 / 31$ & -17.4 & 13.7 & 0.7094 & & & \\
\hline Mixed sediments & $\mathrm{NC} 12 / 19$ & -6 & 12.1 & 0.7092 & & & \\
\hline Mixed sediments & LMU12/2 & -6.2 & 14 & 0.7099 & & & \\
\hline Mixed sediments & LMU12/12 & -9.7 & 14.1 & 0.7077 & & & \\
\hline Mixed sediments & LMU12/18 & -11 & 14.1 & 0.7081 & & & \\
\hline Mixed sediments & $\mathrm{NC} 12 / 34$ & -13.4 & 14.1 & & & & \\
\hline Mixed sediments & LMU12/1 & -6.3 & 14.3 & 0.7099 & & & \\
\hline Mixed sediments & LMU12/14 & -8.4 & 12.3 & 0.7081 & & & \\
\hline Mixed sediments & LMU12/19 & -10.6 & 14.4 & & & & \\
\hline Mixed sediments & LMU12/26 & -10.4 & 14.7 & & & & \\
\hline Mixed sediments & LMU12/39 & -12.2 & 14.8 & 0.7067 & & & \\
\hline Mixed sediments & $\mathrm{NC} 12 / 43$ & -11.2 & 14.9 & 0.7064 & & & \\
\hline Mixed sediments & $\mathrm{NC} 12 / 17$ & -5.5 & 15.7 & 0.7098 & & & \\
\hline Mixed sediments & $\mathrm{NC} 12 / 18$ & -9.3 & 16 & & & & \\
\hline Mixed sediments & LMU12/8 & -8.9 & 16.4 & 0.7064 & & & \\
\hline Mixed sediments & LMU12/7 & -9.1 & 16.4 & 0.7068 & & & \\
\hline Mixed sediments & $\mathrm{NC} 12 / 29$ & -3.8 & 16.5 & 0.7068 & 38.8309 & 15.6402 & 18.5776 \\
\hline
\end{tabular}


Table A1. (Continued.)

\begin{tabular}{|c|c|c|c|c|c|c|c|}
\hline \multirow[b]{3}{*}{ Veins hosted by } & \multirow{3}{*}{$\begin{array}{c}\text { Sample } \\
\text { no. }\end{array}$} & \multicolumn{2}{|c|}{$\begin{array}{l}\text { Stable isotope } \\
(\mathrm{SD}: \pm 0.1 \%)\end{array}$} & \multirow{3}{*}{$\begin{array}{l}\text { Sr isotope } \\
(\mathrm{SD}: 2 \sigma) \\
{ }^{87} \mathrm{Sr} /{ }^{86} \mathrm{Sr}\end{array}$} & \multirow{2}{*}{\multicolumn{3}{|c|}{$\mathrm{Pb}$ isotope (SD: $2 \sigma$ ) }} \\
\hline & & $\delta^{13} \mathrm{C}$ & $\delta^{18} \mathrm{O}$ & & & & \\
\hline & & (VPDB) & (VSMOW) & & ${ }^{208} \mathrm{~Pb} /{ }^{204} \mathrm{~Pb}$ & ${ }^{207} \mathrm{~Pb} /{ }^{204} \mathrm{~Pb}$ & ${ }^{206} \mathrm{~Pb} /{ }^{204} \mathrm{~Pb}$ \\
\hline Mixed sediments & LMU12/32 & -9.5 & 17.4 & 0.7062 & 38.9921 & 15.6656 & 18.6681 \\
\hline Marine sediments & LMU12/27 & -13.3 & 17.3 & 0.7076 & 38.9894 & 15.6649 & 18.6444 \\
\hline Marine sediments & LMU12/34 & -9.1 & 17.6 & 0.7081 & & & \\
\hline Marine sediments & $\mathrm{NC} 12 / 28$ & -2.5 & 17.7 & 0.7071 & & & \\
\hline Marine sediments & LMU12/13 & -6.8 & 17.8 & 0.708 & & & \\
\hline Marine sediments & $\mathrm{NC} 12 / 25$ & -3.9 & 17.9 & & & & \\
\hline Marine sediments & LMU13/1 & -7.7 & 17.9 & & & & \\
\hline Marine sediments & $\mathrm{NC} 12 / 21$ & 1 & 18.8 & & & & \\
\hline Marine sediments & LMU12/38 & -9.9 & 18.8 & & & & \\
\hline Marine sediments & LMU12/36 & -9.8 & 18.9 & & & & \\
\hline Marine sediments & $\mathrm{NC} 12 / 23$ & -1 & 19 & & & & \\
\hline Marine sediments & LMU12/35 & -9.1 & 19 & & & & \\
\hline Marine sediments & $\mathrm{NC} 12 / 26$ & -4.3 & 19.6 & & & & \\
\hline Marine sediments & LMU12/33 & -9.5 & 20.4 & & & & \\
\hline Marine sediments & LMU12/37 & -5.7 & 24.9 & & & & \\
\hline Marine sediments & LMU12/31 & & & 0.7077 & & & \\
\hline
\end{tabular}

\section{References}

Ahmad T, Tanaka T, Sachan H K, Asahara Y, Islam R and Khanna P P 2008 Geochemical and isotopic constraints on the age and origin of the Nidar Ophiolitic Complex, Ladakh, India: Implications for the Neo-Tethyan subduction along the Indus suture zone; Tectonophys. 451(1-4) 206-224, https://doi.org/10.1016/j.tecto.2007.11.049.

Brookfield M and Andrews-Speed C 1984 Sedimentology, petrography and tectonic significance of the shelf, flysch and molasse clastic deposits across the Indus suture zone, Ladakh, NW India; Sedim. Geol. 40(4) 249-286, https:// doi.org/10.1016/0037-0738(84)90011-3.

Burkhard M 1993 Calcite twins, their geometry, appearance and significance as stress-strain markers and indicators of tectonic regime - a review; J. Struct. Geol. 15(3-5) 351368, https://doi.org/10.1016/0191-8141(93)90132-T.

Castor S B and Hedrick J B 2006 Rare earth elements (7th edn); Industrial Minerals and Rocks, Society for mining, metallurgy, and exploration, Littleton, Colorado, pp. 769792.

Clift P, Blusztajn J, Krol M, Carter A, Kirby E and Green O 1999 Timing of collision and patterns of early uplift along the Indus Suture, Ladakh Himalaya, India; EOS, Trans.-AGU 80313.

Clift P D, Degnan P J, Hannigan R and Blusztajn J 2000 Sedimentary and geochemical evolution of the Dras forearc basin, Indus suture, Ladakh Himalaya, India; Geol. Soc. Am. Bull. 112(3) 450-466, https://doi.org/10.1130/ 0016-7606(2000)112\&lt0450:Sageot\&gt2.3.Co;2.

Clift P D, Shimizu N, Layne G D and Blusztajn J 2001 Tracing patterns of erosion and drainage in the Paleogene Himalaya through ion probe $\mathrm{Pb}$ isotope analysis of detrital K-feldspars in the Indus Molasse, India; Earth Planet. Sci. Lett. 188(3-4) 475-491, https://doi.org/10. 1016/S0012-821x(01)00346-6.

Clift P D, Kroon D, Gaedicke C and Craig J 2002a Tectonic and climatic evolution of the Arabian Sea region: An introduction; In: Tectonic and climatic evolution of the Arabian Sea region (eds) Clift P D, Kroon D, Gaedicke C and Craig J, Geol. Soc. London, Spec. Publ. 195 1-5.

Clift P D, Lee J I, Hildebrand P, Shimizu N, Layne G D, Blusztajn J, Blum J D, Garzanti E and Khan A A 2002b Nd and $\mathrm{Pb}$ isotope variability in the Indus River System: Implications for sediment provenance and crustal heterogeneity in the Western Himalaya; Earth Planet. Sci. Lett. 200(1-2) 91-106, https://doi.org/10. 1016/S0012-821x(02)00620-9.

Cox S F 1995 Faulting processes at high fluid pressures - An example of fault valve behavior from the Wattle Gully Fault, Victoria, Australia; J. Geophys. Res.-Sol. Earth 100(B7) 12841-12859, https://doi.org/10.1029/ $95 \mathrm{jb} 00915$.

Dietrich D, McKenzie J A and Song H 1983 Origin of calcite in syntectonic veins as determined from carbon-isotope ratios; Geology 11(9) 547-551, https://doi.org/10.1130/ 0091-7613(1983)11\&lt547:OOCISV\&gt2.0.CO;2.

Faure G 1977 Principles of isotope geology; John Wiley and Sons.

Ferrill D A, Morris A P, Evans M A, Burkhard M, Groshong R H and Onasch C M 2004 Calcite twin morphology: A low-temperature deformation geothermometer; $J$. Struct. Geol. 26(8) 1521-1529, https://doi.org/10.1016/ j.jsg.2003.11.028.

Folling P G, Zartman R E and Frimmel H E 2000 A novel approach to double-spike $\mathrm{Pb}-\mathrm{Pb}$ dating of carbonate 
rocks: Examples from Neoproterozoic sequences in southern Africa; Chem. Geol. 171(1-2) 97-122, https://doi. org/10.1016/S0009-2541(00)00204-7.

Frank W 1977 Geological observations in the Ladakh area (Himalayas). A preliminary report; Schweiz Mineral. Petrogr. Mitt. 57 89-113.

Gansser A 1977 The great suture zone between the Himalaya and Tibet - A preliminary account; Collo. Int. CNRS Paris 268 181-191.

Gao G Q, Elmore R D and Land L S 1992 Geochemical constraints on the origin of calcite veins and associated limestone alteration, Ordovician Viola Group, Arbuckle Mountains, Oklahoma, USA; Chem. Geol. 98(3-4) $257-$ 269, https://doi.org/10.1016/0009-2541(92)90188-B.

Garzanti E and Van Haver T 1988 The Indus clastics: Forearc basin sedimentation in the Ladakh Himalaya (India); Sediment. Geol. 59(3) 237-249, https://doi.org/10.1016/ 0037-0738(88)90078-4.

Garzanti E, Baud A and Mascle G 1987 Sedimentary record of the northward flight of India and its collision with Eurasia (Ladakh Himalaya, India); Geodin. Acta 1(4-5) 297 312, https://doi.org/10.1080/09853111.1987.11105147.

Goswami V, Singh S K, Bhushan R and Rai V K 2012 Temporal variations in $87 \mathrm{Sr} / 86 \mathrm{Sr}$ and $\varepsilon \mathrm{Nd}$ in sediments of the southeastern Arabian Sea: Impact of monsoon and surface water circulation; Geochem. Geophys. Geosyst. 13(1), https://doi.org/10.1029/2011GC003802.

Hart S R 1984 A large-scale isotope anomaly in the Southern Hemisphere mantle; Nature 309 753-757.

Hart S R 1988 Heterogeneous mantle domains-signatures, genesis and mixing chronologies; Earth Planet. Sci. Lett. 90(3) 273-296, https://doi.org/10.1016/ 0012-821x(88)90131-8.

Henderson A L, Foster G L and Najman Y 2010a Testing the application of in situ $\mathrm{Sm}-\mathrm{Nd}$ isotopic analysis on detrital apatites: A provenance tool for constraining the timing of India-Eurasia collision; Earth Planet. Sci. Lett. 297(1-2) 42-49, https://doi.org/10.1016/j.epsl.2010.06.001.

Henderson A L, Najman Y, Parrish R, BouDagher-Fadel M, Barford D, Garzanti E and Ando S 2010b Geology of the Cenozoic Indus Basin sedimentary rocks: Paleoenvironmental interpretation of sedimentation from the western Himalaya during the early phases of IndiaEurasia collision; Tectonics 29(6), https://doi.org/10. 1029/2009tc002651.

Henderson A L, Najman Y, Parrish R, Mark D F and Foster G L 2011 Constraints to the timing of India-Eurasia collision: A re-evaluation of evidence from the Indus Basin sedimentary rocks of the Indus-Tsangpo Suture Zone, Ladakh, India; Earth-Sci. Rev. 106(3-4) 265-292, https://doi.org/10.1016/j.earscirev.2011.02.006.

Honegger K, Dietrich V, Frank W, Gansser A, Thöni M and Trommsdorff V 1982 Magmatism and metamorphism in the Ladakh Himalayas (the Indus-Tsangpo suture zone); Earth Planet. Sci. Lett. 60(2) 253-292, https://doi.org/ 10.1016/0012-821X(82)90007-3.

Khanna P P, Saini N K, Mukherjee P K and Purohit K K 2009 An appraisal of ICP-MS technique for determination of REEs: Long term QC assessment of Silicate Rock Analysis; Him. Geol. 30(1) 95-99.

Kharya A 2015 Isotopic and geochemical studies of the Ladakh accretionary prism, North West Himalaya; PhD
Dissertation, Wadia Institute of Himalayan Geology, University of Petroleum and Energy Studies (India), unpublished.

Martinez-Ruiz F, Ortega-Huertas M and Palomo I 1999 Positive Eu anomaly development during diagenesis of the $\mathrm{K} / \mathrm{T}$ boundary ejecta layer in the Agost section (SE Spain): Implications for trace element remobilization; Terra Nova 11(6) 290-296.

McArthur J, Howarth R and Shields G 2012 Strontium isotope stratigraphy; In: The geologic time scale, Elsevier, pp. 127-144.

Menegatti A P, Weissert H, Brown R S, Tyson R V, Farrimond P, Strasser A and Caron M 1998 High resolution $\delta^{13} \mathrm{C}$ stratigraphy through the early Aptian Livello selli of the Alpine tethys; Paleoceanography 13(5) 530-545.

Mukherjee P K, Khanna P P and Saini N K 2014 Rapid determination of trace and ultra trace level elements in diverse silicate rocks in pressed powder pellet targets by LA-ICP-MS using a matrix independent protocol; Geostand. Geoanal. Res. 38(3) 363-379, https://doi.org/10. 1111/j.1751-908X.2013.00260.x.

Paul D and Skrzypek G 2007 Assessment of carbonatephosphoric acid analytical technique performed using GasBench II in continuous flow isotope ratio mass spectrometry; Int. J. Mass Spectrom. 262(3) 180-186, https://doi.org/10.1016/j.ijms.2006.11.006.

Perkins G B, Sharp Z D and Selverstone J 2006 Oxygen isotope evidence for subduction and rift-related mantle metasomatism beneath the Colorado Plateau-Rio Grande rift transition; Contrib. Mineral. Petrol. 151(6) 633-650, https://doi.org/10.1007/s00410-006-0075-6.

Rai S K and Singh S K 2007 Temporal variation in Sr and ${ }^{87} \mathrm{Sr} /{ }^{86} \mathrm{Sr}$ of the Brahmaputra: Implications for annual fluxes and tracking flash floods through chemical and isotope composition; Geochem. Geophys. Geosyst. 8(8), https://doi.org/10.1029/2007GC001610.

Ray J S and Ramesh R 2006 Stable carbon and oxygen isotopic compositions of Indian carbonatites; Int. Geol. Rev. 48(1) 17-45, https://doi.org/10.2747/0020-6814.48. 1.17 .

Searle M P 1986 Structural evolution and sequence of thrusting in the High Himalayan, Tibetan-Tethys and Indus suture zones of Zanskar and Ladakh, Western Himalaya; J. Struct. Geol. 8(8) 923-936, https://doi.org/10.1016/ 0191-8141(86)90037-4.

Searle M P, Pickering K T and Cooper D J W 1990 Restoration and evolution of the Intermontane Indus Molasse Basin, Ladakh Himalaya, India; Tectonophys. 174(3-4) 301-314, https://doi.org/10.1016/0040-1951(90)90327-5.

Shah S, Sharma M, Gergan J and Tara C 1976 Stratigraphy and structure of the western part of the Indus Suture belt, Ladakh, Northwest Himalaya; Him. Geol. 6 534-556.

Sibson R H 1986 Brecciation processes in fault zones: Inferences from earthquake rupturing; Pure Appl. Geophys. 124(1-2) 159-175.

Sibson R H, Robert F and Poulsen K H 1988 High-angle reverse faults, fluid-pressure cycling, and mesothermal gold-quartz deposits; Geology 16(6) 551-555, https://doi. org/10.1130/0091-7613(1988)016*0551:Harffp*2.3.Co;2.

Sinclair H D and Jaffey N 2001 Sedimentology of the Indus Group, Ladakh, northern India: Implications for the timing of initiation of the Palaeo-Indus river; J. Geol. Soc. 
London 158(1) 151-162, https://doi.org/10.1144/jgs.158. 1.151.

Stipp M, Stunitz H, Heilbronner R and Schmid S M 2002 The eastern Tonale fault zone: A 'natural laboratory' for crystal plastic deformation of quartz over a temperature range from 250 to $700^{\circ}$ C; J. Struct. Geol. 24(12) 18611884, https://doi.org/10.1016/S0191-8141(02)00035-4.

Stipp M, Tullis J, Scherwath M and Behrmann J H 2010 A new perspective on paleopiezometry: Dynamically recrystallized grain size distributions indicate mechanism changes; Geology 38(8) 759-762, https://doi.org/ 10.1130/G31162.1.

Taylor H P, Frechen J and Degens E T 1967 Oxygen and carbon isotope studies of carbonatites from the Laacher See district, West Germany and the Alnö District, Sweden; Geochim. Cosmochim. Acta 31(3) 407-430, https:// doi.org/10.1016/0016-7037(67)90051-8.

Thakur V 1981 Regional framework and geodynamic evolution of the Indus-Tsangpo suture zone in the Ladakh Himalayas; Trans. Roy. Soc. Edinb.: Earth Sci. 72(02) 89-97.

Thakur V and Rawat B 1992 Geologic map of Western Himalaya; Wadia Institute of Himalayan Geology, Dehradun.

Thirlwall M 2002 Multicollector ICP-MS analysis of Pb isotopes using a ${ }^{207} \mathrm{~Pb}^{204} \mathrm{~Pb}$ double spike demonstrates up to $400 \mathrm{ppm} / \mathrm{amu}$ systematic errors in Tl-normalization; Chem. Geol. 184(3-4) 255-279, https://doi.org/10.1016/ S0009-2541(01)00365-5.

Tonarini S, Villa I M, Oberli F, Meier M, Spencer D A, Pognante U and Ramsay J G 1993 Eocene age of eclogite metamorphism in Pakistan Himalaya: Implications for India-Eurasia collision; Terra Nova 5(1) 13-20, https:// doi.org/10.1111/j.1365-3121.1993.tb00221.x.

Tullis J and Yund R A 1985 Dynamic recrystallization of feldspar: A mechanism for ductile shear zone formation; Geology 13(4) 238-241, https://doi.org/10.1130/ 0091-7613(1985)13*238:DROFAM*2.0.CO;2.
Van Haver T 1984 Etude stratigraphique, sédimentologique et structurale d'un bassin d'avant arc: exemple du bassin de l'Indus, Ladakh, Himalaya; Dissertation, GrenoblePublished, Univ. de Grenoble, France.

Vernon R 1981 Optical microstructure of partly recrystallized calcite in some naturally deformed marbles; Tectonophys. 78(1) 601-612, https://doi.org/10.1016/ 0040-1951(81)90031-7.

Weinberg R F 1997 The disruption of a diorite magma pool by intruding granite: The Sobu body, Ladakh batholith, Indian Himalayas; J. Geol. 105(1) 87-98, https://doi.org/ $10.2307 / 30079887$.

Weinberg R F and Dunlap W J 2000 Growth and deformation of the Ladakh batholith, northwest Himalayas: Implications for timing of continental collision and origin of calc-alkaline batholiths; J. Geol. 108(3) 303-320, DOI: https://doi.org/10.1086/314405.

White W M and Hofmann A W $1982 \mathrm{Sr}$ and Nd isotope geochemistry of oceanic basalts and mantle evolution; Nature 296 821-825.

Will T M, Frimmel H E, Zeh A, Le Roux P and Schmadicke E 2010 Geochemical and isotopic constraints on the tectonic and crustal evolution of the Shackleton Range, East Antarctica, and correlation with other Gondwana crustal segments; Precamb. Res. 180(1-2) 85-112, https://doi. org/10.1016/j.precamres.2010.03.005.

Wu Y B, Zheng Y F, Zhang S B, Zhao Z F, Wu F $\mathrm{Y}$ and Liu X M 2007 Zircon U-Pb ages and $\mathrm{Hf}$ isotope compositions of migmatite from the North Dabie terrane in China: Constraints on partial melting; J. Metamorph. Geol. 25(9) 991-1009, https://doi.org/10.1111/j. 1525-1314.2007.00738.x.

Yamaguchi A, Ujiie K, Nakai S I and Kimura G 2012 Sources and physicochemical characteristics of fluids along a subduction-zone megathrust: A geochemical approach using syn-tectonic mineral veins in the Mugi mélange, Shimanto accretionary complex; Geochem. Geophys. Geosyst. 13(7), https://doi.org/10.1029/2012GC004137. 